\title{
Siberian flying squirrels do not anticipate future resource abundance
}

Vesa Selonen ${ }^{1 *}$ and Ralf Wistbacka ${ }^{2}$

\begin{abstract}
Background: One way to cope with irregularly occurring resources is to adjust reproduction according to the anticipated future resource availability. In support of this hypothesis, few rodent species have been observed to produce, after the first litter born in spring, summer litters in anticipation of autumn's seed mast. This kind of behaviour could eliminate or decrease the lag in population density normally present in consumer dynamics. We focus on possible anticipation of future food availability in Siberian flying squirrels, Pteromys volans. We utilise long-term data set on flying squirrel reproduction spanning over 20 years with individuals living in nest-boxes in two study areas located in western Finland. In winter and early spring, flying squirrels depend on catkin mast of deciduous trees. Thus, the temporal availability of food resource for Siberian flying squirrels is similar to other mast-dependent rodent species in which anticipatory reproduction has been observed.
\end{abstract}

Results: We show that production of summer litters was not related to food levels in the following autumn and winter. Instead, food levels before reproduction, in the preceding winter and spring, were related to production of summer litters. In addition, the amount of precipitation in the preceding winter was found to be related to the production of summer litters.

Conclusions: Our results support the conclusion that Siberian flying squirrels do not anticipate the mast. Instead, increased reproductive effort in female flying squirrels is an opportunistic event, seized if the resource situation allows.

Keywords: Resource pulse, Masting, Demographic responses

\section{Background}

One way to cope with irregularity of resource availability is to adjust reproduction according to the anticipated future resource availability [1-4]. This would be particularly useful in resource pulse systems, where resource levels fluctuate remarkably over time [5]. Due to the unpredictable nature of resource pulses animals may be doomed to boom and bust dynamics with dramatic population decline when the resource pulse is over [5]. Anticipation of the resource pulse [1] or anticipation of resource crash [6] could eliminate the lag in population density normally present in consumer dynamics.

A common cause for fluctuation in recourse levels in forest communities is masting by trees, synchronous

\footnotetext{
*Correspondence: vessel@utu.fi

1 Department of Biology, Section of Ecology, University of Turku, 20014 Turku, Finland

Full list of author information is available at the end of the article
}

production of large seed crops, which dramatically affects the whole forest community $[5,7,8]$. For example, densities of seed predators often peak in spring-summer following the resource pulse from the previous autumn [7, $9,10]$. To optimize reproduction with masting events, it is suggested that in European and North American red squirrels $[1,10]$, chipmunks [11] and fat dormice [12] a mother may increase reproductive output in summers before mast autumns. However, the role of this behaviour in population dynamics of the species remains uncertain $[13,14]$. It also remains unclear how general the anticipation behaviour might be for rodents living in forest communities [15].

In this study we test whether Siberian flying squirrels, Pteromys volans (hereafter flying squirrels), which depend upon resource pulses of catkins from deciduous trees [16, 17], are able to anticipate current year's resources in fall by increasing reproductive output in 
summer. Earlier red squirrel and chipmunk studies have indicated that summer litters are produced in anticipation, whereas spring litters are less affected by future food conditions $[10,13,14]$. Thus, we focus our analysis on production of summer litters in flying squirrels.

We predict that (1) if flying squirrels anticipate the abundance of food resources available to juveniles in the winter of their first year, the production of summer litters is related to resource levels in the following autumn and winter. If flying squirrels do not anticipate the resource availability (2) the production of summer litters is related to the resource abundance in the preceding winter and spring. In addition to the food availability, climate is an important determinant of animal reproduction [18]. Thus, we also analyse whether (3) temperature and precipitation preceding reproduction affects the production of summer litters in flying squirrels.

\section{Methods}

\section{Study species and its food}

The Siberian flying squirrel is a nocturnal, arboreal rodent, which nests in tree cavities, nest-boxes and dreys in spruce-dominated boreal forests. The flying squirrel feeds in deciduous trees that occur within spruce forests, birch, Betula pubescens/pendula, alder, Alnus incana/glutinosa, and aspen, Populus tremula, being the only used deciduous trees in our study areas [19-21; own observation]. During winter and early spring, when flying squirrel mating, pregnancy and parturition of spring litters occur, birch and alder catkins are the main food of flying squirrels [19, 22; Fig. 1]. Birch catkins form the main part of the winter diet ( $80 \%$ of used food, based on faecal diet analysis; [20]), but only alder catkins are stored and are preferred over birch based on analysis of use versus availability [20-22; Fig. 2]. Catkins begin development during the previous summer, and flying squirrels may start to consume them in autumn [20], continuing to do so during the following winter and early spring (Fig. 1). Catkins flower in spring and birch catkins, which are not stored, are not available when reproductive decisions for summer litters are made. How long alder catkins can be stored in caches is not known, such storage prolongs the time period that catkins are edible, as it prevents catkins from flowering. Catkin production varies considerably between years [16, 17]; see 23] for frequency of pulses in our study areas. Catkin production increases when the previous summer has been warm, however, trees seldom manage to produce mast for two successive years [17, 23]. After the opening of leaves, on average in the beginning of May in our study areas, leaves form major part of late spring and summer diet, together with flower buds of conifers $[20,21]$. However, during pregnancy and parturition of spring litters, females may still use catkins, since females are in oestrus and mating occurs starting from mid-March. Spring litters are born in late April. After the spring litter, the second (summer) litter may be born in June, gestation starting in May [24]. Females seem to be territorial, living in separate on average 7 ha home ranges, but males live in overlapping on average 60 ha home ranges encompassing several males and females [25].

\section{Study areas and data gathering}

The studies on flying squirrels were done with individuals living in nest-boxes in two study areas located in western Finland: Luoto $\left(63^{\circ} 49^{\prime} \mathrm{N}, 22^{\circ} 49^{\prime} \mathrm{E}\right)$ and Vaasa $\left(63^{\circ} 3^{\prime} \mathrm{N}\right.$, $22^{\circ} 41^{\prime} \mathrm{E}$ ), located about $100 \mathrm{~km}$ from each other. We do not know any obvious behavioural or reproductive differences between individuals living in nest-boxes, dreys, or natural cavities [26], nor in predator community between sites. The entrance-hole diameter of nest-boxes was $4.5 \mathrm{~cm}$. This entrance-hole size prevents main predators
Previous year's catkin production

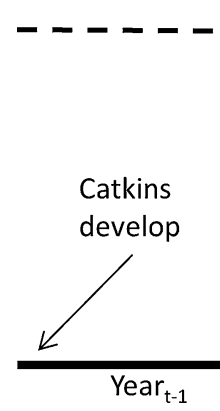

Autumn

\section{Alder storages}

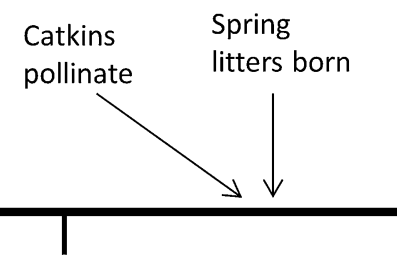

Winter

\section{Current year's catkin production}

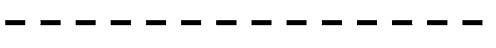

Summer litters

Juveniles Catkins

disperse develop

born

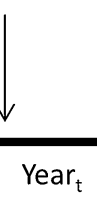

Spring

Summer

Autumn

Year $_{t+1}$

Fig. 1 Timeline including the period when alder and birch catkins are consumable (dashed line) by flying squirrels, and the timing of birth of flying squirrel spring and summer litters. Only alder catkins are stored, but how long catkins can be stored in caches is not known 


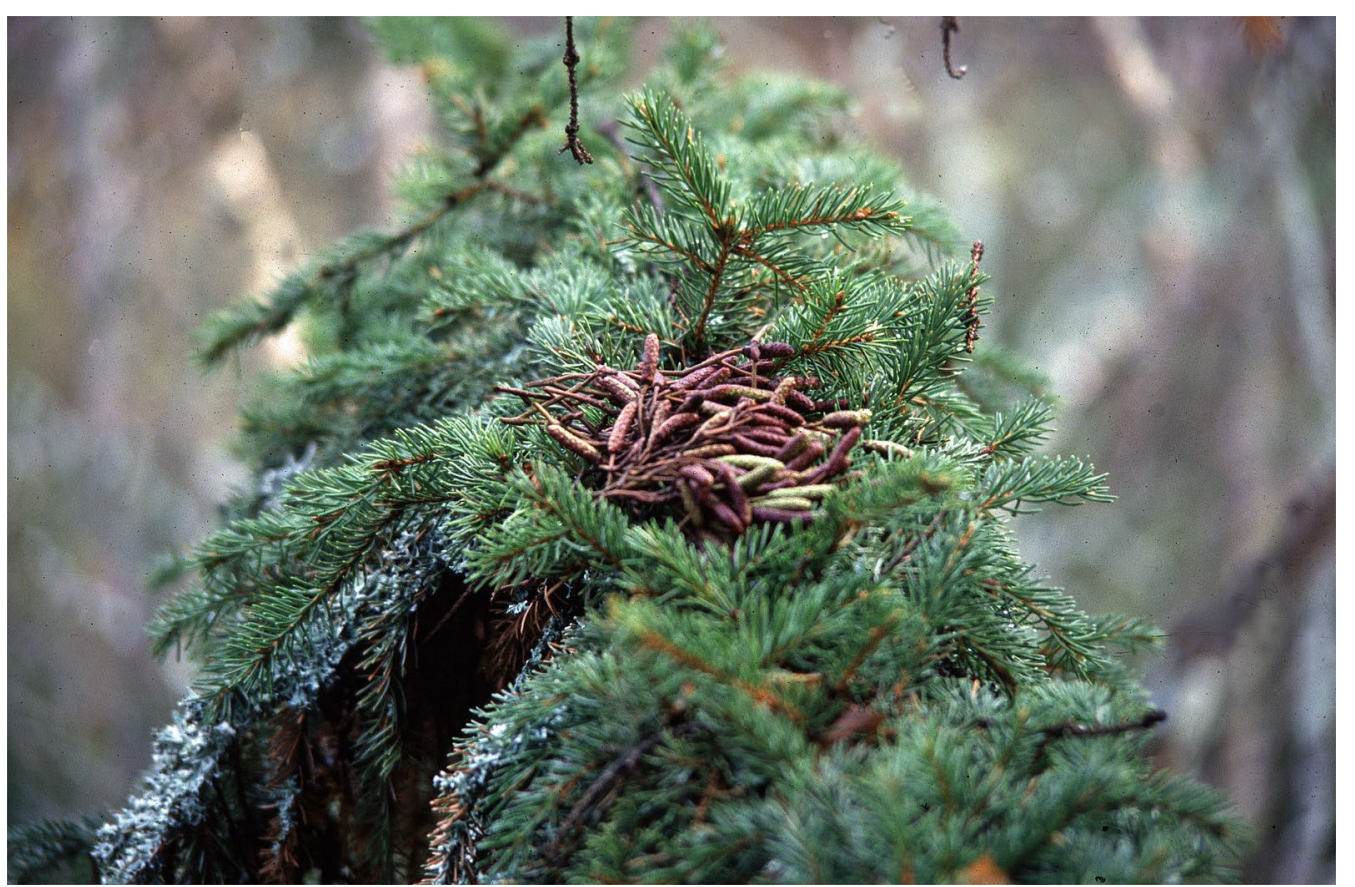

Fig. 2 An example of alder catkin storage made by a flying squirrel. Catkins are cached typically on branches of spruces high up in trees, as in this case, and also sometimes in cavities and nest-boxes. An individual can make several different caches. OPertti and Risto Sulkava

(the pine marten, Martes martes, and large owls) entering the nest box. Nest-boxes were made from a piece of aspen or spruce trunk, so that they resembled natural cavities. Natural cavities were rare in our study areas (on average 0.1 cavities per hectare based on 742 spruce forest hectares surveyed within our study areas).

In Luoto flying squirrels were studied during 19932014 within an area of $44 \mathrm{~km}^{2}$, where between 300 and 400 nest-boxes were placed for flying squirrels. The main forest types in Luoto are shoreline spruce-dominated mixed forests, clear-cuts, and cultivated Scots pine forests. In Vaasa the marking of flying squirrels started in 1992. The Vaasa study area was $25 \mathrm{~km}^{2}$ and is covered by spruce forest patches, clear-cuts, and agricultural fields (for more information see [26, 27]. 200-400 nest-boxes were placed within the Vaasa study area to be used by flying squirrels during the study period.

We placed flying squirrel nest-boxes in forest patches of various sizes in sets of 2-4 nest-boxes per site, on average two nest-boxes per mature spruce forest hectare. Box occupancy percentage by the flying squirrel was low ( $25 \%$ nest box occupancy), that is, in most cases a nest box was empty when checked. Flying squirrels were captured by hand in nest-boxes, sexed, weighed, and marked with ear-tags (Hauptner 73850, Hauptner, Germany). The nest-boxes were checked during two sessions in June and August. The latter session was for locating summer litter juveniles. All boxes were checked in spring, but on our second (August) nest box session we focused only on nest box sites occupied by females during the spring (June) nest-box check.

We calculated the number of summer litters occurring in both study areas each year (Table 1), spring litter production of flying squirrels is analysed in [23]. For analysis of summer litters we only included cases where the female was witnessed to successfully produce the spring litter juveniles close to weaning age. In some cases we observed only late born litters without knowledge whether the mother had produced the spring litter. These cases were omitted from the data, because we did not know whether we missed the spring litter (it could be in drey, i.e. a twig nest) or whether the female failed to produce the spring litter. Number of omitted litters was on average $1.1 \pm 0.9$ litters in Luoto and $1.3 \pm 1.5$ litters in Vaasa per year. The occurrence of these omitted litters was positively correlated with the number of summer litters born to mothers with observed spring litter each year (estimate $0.15 \pm 0.07 ; \mathrm{F}_{40}=4.80, \mathrm{p}=0.03$ ). During the first nest-box checking session (mean date 14th June) litters had not been weaned (mean weight $59 \pm 11 \mathrm{~g}$ ). The summer litters were on average $56 \pm 12 \mathrm{~g}$ during the second nest box checking session on average in 18th of August (during this time spring litter juveniles are around 100 g; adult body mass is usually $100-150 \mathrm{~g}$ ). 
Table 1 Data for spring litters $(n=640)$ and summer litters $(n=93)$ within the two flying squirrel study areas

\begin{tabular}{|c|c|c|}
\hline & Vaasa (mean \pm SD) & Luoto $($ mean \pm SD) \\
\hline \multicolumn{3}{|l|}{ Spring litters } \\
\hline No of litters ${ }^{\mathrm{a}}$ & $\mathrm{n}=404,18 \pm 11$ per year & $\mathrm{n}=236,12 \pm 6$ per year \\
\hline Litter size $^{b}$ & $2.5 \pm 0.72$ & $2.5 \pm 0.86$ \\
\hline Body mass ${ }^{c}$ & $58 \pm 11 \mathrm{~g}$ & $60 \pm 10 \mathrm{~g}$ \\
\hline \multicolumn{3}{|l|}{ Summer litters } \\
\hline No of litters & $\mathrm{n}=70,3.3 \pm 3.5$ per year, $\min 0, \max 12$ & $\mathrm{n}=23,1.2 \pm 1.1$ per year, $\min 0, \max 4$ \\
\hline Litter size $^{b}$ & $2.3 \pm 0.8$ & $2.6 \pm 0.7$ \\
\hline Body mass ${ }^{c}$ & $54 \pm 11 \mathrm{~g}$ & $59 \pm 12 \mathrm{~g}$ \\
\hline Years studied & 1992-2014 & $1993-2014^{d}$ \\
\hline
\end{tabular}

a Number of sites with spring litters and checked to locate the possible summer litter

b Mothers with summer litter: $2.48 \pm 0.65, \mathrm{n}=88$ and Mothers without summer litter: $2.52 \pm 0.8, \mathrm{n}=547$

c Body mass at capture on average 14th of June for spring litter and 18th of August for summer litter

d Luoto: years 2007 and 2008 omitted due to lack of data

\section{Food abundance indices}

We used estimates from an annual birch-catkin survey conducted by the Finnish Forest Research Institute [28] to estimate food available to flying squirrels each year. These data describe nation-wide pollen availability in Finland. Birch catkins were counted in winter from seed-crop observation stands. The catkin data originated from 15 permanent research stands, where catkins were counted from 30 to 50 birches per stand. Observations were made repeatedly from the same individual trees each year [28]. At our Vaasa study site, a seed-crop observation stand was located within the study area. The closest seed-crop observation stand to our Luoto study site was the Vaasa observation stand located $90 \mathrm{~km}$ away. Thus, we used Vaasa indices for both of our study areas, since according to previous analysis of this catkin data, correlation between two sampling sites at this distance is high $(\mathrm{r} \approx 0.7)$, because catkin production of deciduous trees is spatially correlated at scales of up to few hundred kilometers in Finland [16]. Although the food index for Luoto is less accurate than for Vaasa, it describes the yearly variation in catkin production in the area. Both study areas located in coastal area with very similar weather conditions.

For alder there was no catkin count data, but as a proxy we used aerial pollen estimates that correlate with catkin production [16]. Pollen data was collected by the aerobiology unit at University of Turku. Pollen samples were collected from 10 different locations in Finland with EU standard methods and Burkard samplers. The data consisted of accumulated sums of average daily counts of airborne pollen in $1 \mathrm{~m}^{3}$ of air during spring (16; http://www. siitepoly.fi/en/). Similarly as above for birch catkin data, we used Vaasa sampling site for both of our study areas.
Alder pollen and birch catkin data are correlated, albeit not very strongly $\left(r^{2}=0.31\right.$ for years $1992-2014$ in our dataset).

\section{Weather indices}

We used weather information from the closest weather station maintained by the Finnish Meteorological Institute to both study areas. For Vaasa the closest weather station was located within our study area, and for Luoto it was $10 \mathrm{~km}$ southeast of the study area. Weather recording stations were at the same altitude with study areas.

We used monthly average weather indices from November prior to gestation to June following lactation. We selected the following periods: For winter weather, we used average temperature and the amount of precipitation in December-January (early winter) and the average temperature and amount of precipitation in FebruaryMarch (late winter) in our analysis. For spring weather, instead of monthly average temperatures, we used (1) the start date of the growing season, that is, the date after which the average daily temperature in spring was permanently above $+5{ }^{\circ} \mathrm{C}$. Additionally, we used (2) growing degree days in April and May (the sum of degrees that in daily average temperature were above $5{ }^{\circ} \mathrm{C}$ in a given month). These indices were assumed to describe spring conditions better than mere temperature, although we also tested the effect of temperature in April-May. Temperature permanently above $+5^{\circ} \mathrm{C}$ is determined to indicate start of growing season by Finnish Meteorological Institute (http://en.ilmatieteenlaitos.fi/seasons-in-finland) and has been observed, for example, to well correspond to birch bud burst in Finland [29]. Lastly, we used precipitation in April-May and temperature and precipitation in June (summer) in our analyses. 


\section{Analysis}

Despite the obvious correlations between different weather and resource data, the explanatory variables were relatively independent from each other. We did not allow the variables, past birch and start of growing season, in the same model. This resulted in low collinearity between variables (Variance inflation factor values $<2$, Proc Reg, SAS 9.3).

To analyse the effects of different food and weather variables on occurrence of summer litters, we used multimodel inference based on Akaike's information criterion (AIC, smaller values being better). We used AICc values designed for a small sample size and did not include more than three explanatory variables at a time to the model to avoid over-parameterisation. This was done because, in this analysis, the sampling unit was a year. If there was no single clear best fit model or parameter, we used model averaging, using cut-off $\triangle \mathrm{AIC}$ of 10 and including all models where the term of interest appeared [30]. From the results of model averaging, we considered a parameter to be important in explaining squirrel reproduction if its coefficient and associated 95\% confidence interval did not include zero (the obtained results were the same, if we used generalized linear models, analysis not shown). We built models with binomial distribution with GLIMMIX (SAS), using the events/trial option, such that the 'event' was the number of summer litters observed and the 'trial' was the total number of sites that had a spring litter and that were inspected for a possible summer litter in each study area each year. The explanatory variables were future (current years' autumn and winter following lactation and weaning) and past (previous winter and spring preceding gestation) catkin production of birch or pollen estimate of alder and aspen (proxy for catkin production) and above described temperature and precipitation estimates before reproduction. The study area was selected as a class variable in the model.

To gain further information on recourse availability/ female condition before production of summer litters, we compared body mass of spring litters born to mothers with summer litters and spring litters born to mothers without summer litters. If spring litters were large when observed (born earlier and/or grown faster) that indicates good resource situation before reproduction [23]. For this analysis we only used litters weighed during the same day each year (body mass was calculated as an average for a litter). In addition, we tested whether the age of mother affected its likelihood to have a summer litter. For this analysis we used only females ear-tagged as juveniles, so that the exact age of individual was known. Whether or not a female was observed to produce one or two litters a year was a dependent variable (binomial distribution). The age of the mother as well as the study area were selected as explanatory variables. The ID of the mother was a random variable using Kenward-Roger method to determine degrees of freedom. Finally, with binomial model we tested whether or not a female had summer litter was related to the size of its spring litter. In this model individual ID and year were random variables; study area was included as class variable. The above analyses were done with generalized linear mixed models in GLIMMIX, SAS.

\section{Results}

We had data for 547 females with only a spring litter and 93 females with both summer and spring litters (total 733 litters; Table 1). Thus, about $15 \%$ of mothers were observed to produce summer litters (Figs. 3, 4). Litter sizes were quite similar between summer and spring litters (Table 1) and the size of spring litter was not related to likelihood to produce a summer litter $\left(\mathrm{F}_{1,323.8}=1.3\right.$, $\mathrm{p}=0.24$; Table 1 ). The mother's age (age range $1-6$ years) was not related to the likelihood of producing summer litters $\left(\mathrm{n}=111\right.$ cases; $\left.\mathrm{F}_{1,24}=0.32, \mathrm{p}=0.58\right)$.

Summer litters were not produced in anticipation of the future resource availability in the autumn and winter of a juvenile's first year. Instead, alder catkin production during winter and spring before reproduction was significantly related to occurrence of summer litters (coefficient 1.5, 95\% CI 1.1 and 2.1; Fig. 4). The top models explaining the occurrence of summer litters included also birch catkins before reproduction and early winter rain (Fig. 3; Table 2). The effect of early winter rain was significant in the model (coefficient 2.1, 95\% CI 1.0 and 3.1) but birch had no obvious effect (coefficient 0.29, 95\% CI -0.02 and 0.6). Future alder and birch estimates clearly lowered the model fit (Table 2; increase in $\triangle \mathrm{AIC}$, alder: 26, birch: 29). Future alder pollen production had a significant, but negative, effect (coefficient $-0.30,95 \% \mathrm{CI}$ -0.05 and -0.65 ; Fig. 4 ), because a mast year with a high number of summer litters is typically followed by a low resource year (Fig. 3). Body mass of juveniles in spring litters born to mothers with summer litters was on average $5 \pm 6$ g larger than body mass of juveniles in spring litters born to mothers without summer litters (difference to expected $0 \mathrm{~g}$ difference: $\left.\mathrm{t}_{45}=5.4, \mathrm{p}<0.0001\right)$. In other words, if a female produced summer litter, her spring juveniles were born earlier or grew faster compared to juveniles of females who did not produce summer litters.

\section{Discussion}

We observed that flying squirrels reproductive investment did not anticipate future resource availability. Instead, food levels before reproduction explained increased reproductive effort, in the form of summer litters. In addition, females who produced summer 


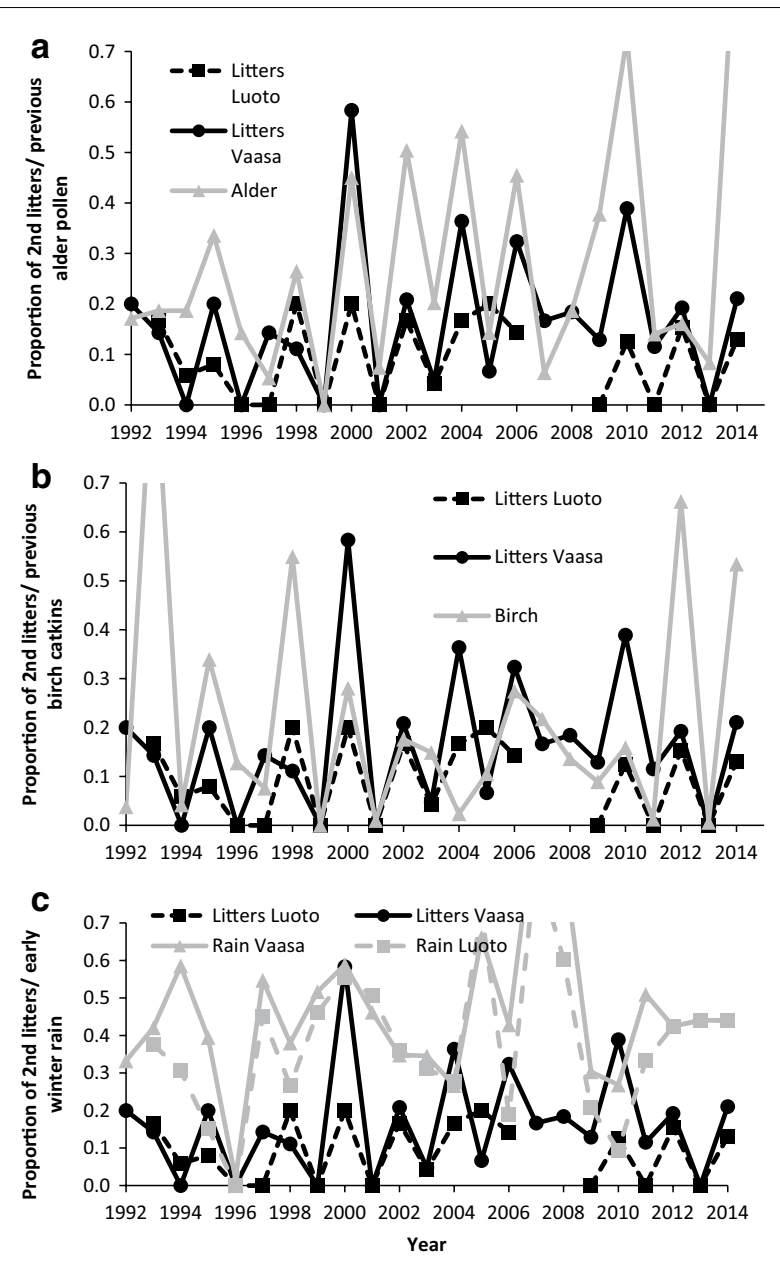

Fig. 3 Yearly variation in proportion of observed summer litters of flying squirrels in two study areas in western Finland and $\mathbf{a}$ alder pollen (proxy for catkin production) and $\mathbf{b}$ birch catkins in winter/spring preceding reproduction. c Rain in early winter preceding reproduction. Alder, birch and rain scaled to values between 0 and 1. Missing data for Luoto for years 2007 and 2008

litters had managed to produce spring litters earlier than females who only produced spring litters. This further supports the conclusion that production of summer litters is related to the condition of a female before reproduction.

Our results support the hypothesis that reproductive decisions are determined by the condition of females at the time of reproduction. This kind of behaviour is typical in, for example, income breeding species, like grazers depending on spring plant growth [31] or insectivorous birds [32]. Foraging behaviour of flying squirrels differs from the behaviour of these species since, in winter and spring flying squirrels depend on food that has already developed during the previous autumn, i.e. an example of a capital breeder strategy. It seems likely

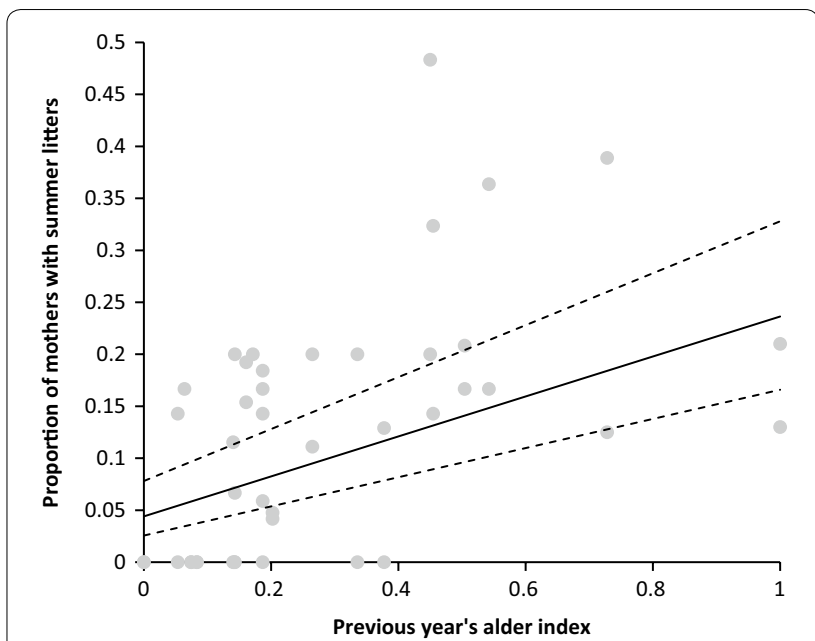

Fig. 4 Effect of alder pollen in preceding spring on production of summer litters by flying squirrels. Solid line based on predicted values with upper and lower lines for confidence interval from best fitted model based on multimodel inference. Alder scaled to values between 0 and 1. Grey dots for raw data

Table 2 Ranking of the best candidate models to explain occurrence of flying squirrel summer litters in Vaasa and Luoto study areas between 1992 and 2014

\begin{tabular}{lccc}
\hline Model $^{\mathbf{a}}$ & AICc & DAICc & $\begin{array}{l}\text { AICc } \\
\text { weight }\end{array}$ \\
\hline Alder_previous + Rdecjan & 117.3 & 0 & 0.26 \\
$\begin{array}{l}\text { Alder_previous + Rdecjan + } \\
\text { birch_previous }\end{array}$ & 117.5 & 0.8 & 0.20 \\
Alder_previous + Rdecjan + Tfebmar & 119.3 & 2.0 & 0.09 \\
$\begin{array}{l}\text { Alder_previous + Rdecjan + } \\
\text { aspen_previous }\end{array}$ & 119.4 & 2.1 & 0.09 \\
Alder_previous + Rdecjan + DdaysApril & 119.5 & 2.2 & 0.09 \\
Alder_previous + Rdecjan + DdaysMay & 119.8 & 2.5 & 0.07 \\
Alder_previous + Rdecjan + TJune & 119.9 & 2.6 & 0.07 \\
Alder_current + Rdecjan & 143.5 & 26.2 & 0 \\
\hline
\end{tabular}

The best model for both the future and the past food availability are shown. The AICC value, as well as the change in $\mathrm{AICC}(\triangle \mathrm{AICC})$ and relative weight of support (AIC weight) are shown for each model. Models with cumulative $W i=0.90$ presented

a Variable names: $T$ temperature in given month; $R$ rain in given month; decjan December-January; febmar February-March; Ddays degree days; Aspen Aspen pollen estimate; Alder alder pollen estimate; Birch birch catkin estimate; previous pollen/catkin estimate available preceding gestation; current current years' pollen/catkin estimate available after lactation and weaning. Study area was included in all models, and it had a significant effect (coefficient and c.l. $>0$ ), since the proportion of summer litters was low in Luoto likely due to a lower density of nest-boxes in Luoto than in Vaasa

that storages of alder catkins are important for fuelling reproduction of flying squirrels in summer, since the alder was more clearly related to reproduction than was birch catkin production, an important, but not cached, winter food. 
After successfully weaning the spring litter, reproducing again during the same summer seems to require good environmental conditions. The observed relationship between food resources and production of summer litters was clear (Figs. 3a, 4). However, the proportion of mothers with summer litters may be slightly underestimated, since it is possible that we missed a few summer litters, if some females moved from nest boxes to dreys (twig nest). In particular in the Luoto study area, the low number of summer litters is likely due to a lower nest-box density in this study area than in the Vaasa study area [26], which lowers the likelihood of finding summer litters. Nevertheless, both study areas gave similar support for the effect of past alder catkin availability on production of summer litters in flying squirrels.

Weather was also linked to production of summer litters in flying squirrels. Surprisingly, precipitation in winter prior to gestation, not the temperature in spring or summer, was linked to the occurrence of summer litters. It remains unclear what is behind this observed correlation, and in the time-series of the data (Fig. 3c) the relationship was not very clear. However, the lack of sufficient soil moisture is an important stress factor for deciduous trees [33], and it is possible that dry or snowless winter conditions affect moisture conditions and consequently flowering buds or leaves in spring and summer, which provide food for flying squirrels. Indeed, the quality of summer food is a likely candidate that affects summer reproduction of the species. Unfortunately, we were unable to directly study this, but leaf growth is tightly linked to weather conditions during the time period included in our analysis. In any case, the effect of weather on production of summer litters needs further study due to correlative nature of our analysis.

Our results from flying squirrels provide an example of forest-dependent rodent species not able to anticipate a mast. This result is in contrast to observations in some other studies on rodents $[1,10,11,34,35]$. For example, North American red squirrels [1] are likely more dependent on cached food than Siberian flying squirrels. North American red squirrels clip new spruce cones containing seeds each autumn and cache them in a larder hoard called a midden [36, 37]. The dependency on middens [38] might increase the adaptive reasons to anticipate the mast in North American red squirrels. However, anticipation is suggested to also occur in forest rodents other than North American red squirrels [10, 11, 34]. The adaptive reasons to anticipate the mast should occur also in flying squirrels as the production of food consumed by flying squirrels is quite similar to that of, for example, Eurasian red squirrels [10]. Flying squirrels start to consume catkins in autumn and continue to do so during the following winter and early spring, when the catkins flower. Thus, if a female could anticipate the coming mast, its offspring would face the winter with optimal resource availability. In addition, variance in birch and alder catkin production [23] is comparable to variation in spruce cone production used by red squirrels [1, 14]. Furthermore, the Siberian flying squirrel are entirely dependent on trees, and very seldom move on the ground (North American flying squirrels, Glaucomys spp., move regularly on the ground, e.g. when they harvest truffles). In winter the only foods available for flying squirrels are catkins and buds. However, during summer food other than catkins seems to be sufficient for reproduction as some summer litters were also produced following poor catkin winters. Thus, mast conditions do not appear to be essential for the production of summer flying squirrel litters.

For species observed to anticipate mast, it has previously been speculated that buds that eventually develop into cones/seeds are used to predict the future resource availability [1,36]. For example, the edible dormouse, Glis glis, has been suggested to use the flower buds of the European beech, Fagus sylvatica, in spring as a sign of mast $[12,35]$. The dormice gain energy from eating these buds, and it has also been observed that food supplementation in spring increases the summer production of this species $([12,35]$; however, for North American red squirrels see $[1,39])$. Similarly, in flying squirrels, abundant food resources in the spring were positively correlated with the production of summer litters. However, for dormice the situation is different, as increased energy from flower buds also correlates with a future good seed situation that will benefit the offspring the next autumn and winter [40, 41]. With flying squirrels, the juveniles from summer litters will face the winter without catkins, since mast is generally followed by poor investment in reproduction by trees [42]. This may be problematic, since the survival rate of rodent juveniles is generally highest in mast conditions [43].

\section{Conclusions}

We observed that Siberian flying squirrels do not anticipate the coming mast, but instead adjust their reproductive decision based on current and past food availability. For flying squirrels, an increased reproductive effort is simply a consequence of favourable environmental conditions, which allow females to increase offspring production. The reproductive strategy of Siberian flying squirrels appears to be an opportunistic strategy, depending on the current resource availability, without possibilities to anticipate the future conditions the offspring will face when they mature. 


\section{Authors' contributions}

RW collected data, VS analysed data and wrote the manuscript. Both authors read and approved the final manuscript.

\section{Author details}

${ }^{1}$ Department of Biology, Section of Ecology, University of Turku, 20014 Turku, Finland. ${ }^{2}$ Department of Biology, University of Oulu, 90014 Oulu, Finland.

\section{Acknowledgements}

We thank all of the field workers, Timo Hyrsky, Rune Jakobsson, Antero Mäkelä and Markus Sundell, who have assisted during data gathering. Annika Saarto kindly provided the catkin and pollen data. Leigh Ann Lindholm gave valuable comments on an earlier version of the manuscript.

\section{Competing interests}

The authors declare that they have no competing interests.

\section{Availability of data and material}

The data set supporting the results of this article is available in the Eurasian Chronicle of Nature (formerly European Boreal Forest Biodiversity, EBFB) database repository, https://www.earthcape.com/.

\section{Ethics approval and consent to participate}

All applicable international, national, and/or institutional guidelines for the care and use of animals were followed. No ethical approval was required from an institutional or national ethics review board.

\section{Funding}

The study was financially supported by Oskar Öflunds stiftelse (to RW), Societas Pro Fauna et Flora Fennica (to RW), Vuokon luonnonsuojelusäätiö (to RW), the Academy of Finland (Grant number 259562 to VS).

Received: 29 June 2016 Accepted: 2 November 2016 Published online: 14 November 2016

\section{References}

1. Boutin S, Wauters LA, McAdam AG, Humphries MM, Tosi G, Dhondt AA. Anticipatory reproduction and population growth in seed predators. Science. 2006;314:1928-30.

2. Valone TJ. Are animals capable of Bayesian updating? An empirical review. Oikos. 2006;112:252-9.

3. Raby CR, Alexis DM, Dickinson A, Clayton NS. Planning for the future by western scrub-jays. Nature. 2007;445:919-21.

4. Railsback SF, Harvey BC. Trait-mediated trophic interactions: is foraging theory keeping up? Trends Ecol Evol. 2013;28:119-25.

5. Ostfeld RS, Keesing F. Pulsed resources and community dynamics of consumers in terrestrial ecosystems. Trends Ecol Evol. 2000;15:232-7.

6. Lindström E. Reproductive effort in the red fox, Vulpes vulpes, and future supply of a fluctuating prey. Oikos. 1988;52:115-9.

7. Jȩdrzejewska $B$, Jeȩdrzejewski W. Predation in vertebrate communities: the Bialowieza Primeval Forest as a case study. Berlin: Springer-Verlag; 1998.

8. Lobo N, Millar JS. Indirect and mitigated effects of pulsed resources on the population dynamics of a northern rodent. J Anim Ecol. 2013:82:814-25.

9. Bogdziewicz M, Zwolak R, Crone EE. How do vertebrates respond to mast seeding? Oikos. 2016:125:300-7.

10. Wauters LA, Githiru M, Bertolino S, Molinari A, Tosi G, Lens L. Demography of alpine red squirrel populations in relation to fluctuations in seed crop size. Ecography. 2008;31:104-14.

11. Bergeron P, Réale D, Humphries MM, Garant D. Anticipation and tracking of pulsed resources drive population dynamics in eastern chipmunks. Ecology. 2011;92:2027-34

12. Lebl K, Kürbisch K, Bieber C, Ruf T. Energy or information? the role of seed availability for reproductive decisions in edible dormice. J Comp Physiol B. 2010:180:447-56

13. Williams CT, Lane JE, Humphries MM, McAdam AG, Boutin S. Reproductive phenology of a food-hoarding mast-seed consumer: resource- and density-dependent benefits of early breeding in red squirrels. Oecologia. 2014:174:777-88.
14. Selonen $V$, Varjonen $R$, Korpimäki E. Immediate or lagged responses of a red squirrel population to pulsed resources. Oecologia. 2015;177:401-11.

15. White TCR. Mast seeding and mammal breeding: can a bonanza food supply be anticipated? N Z J Zool. 2007;34:179-83.

16. Ranta H, Hokkanen T, Linkosalo T, Laukkanen L, Bondenstam K, Oksanen A. Male flowering of birch: spatial synchronization, year-to-year variation and relation of catkin numbers and airborne pollen counts. Forest Ecol Manage. 2008;255:643-50.

17. Ranta H, Oksanen A, Hokkanen T, Bondestam K, Heino S. Masting by Betula-species; applying the resource budget model to north European data sets. Int J Biometeorol. 2005;49:146-51.

18. White TCR. The role of food, weather and climate in limiting the abundance of animals. Biol Rev. 2008:83:227-48.

19. Mäkelä A. Liito-oravan, Pteromys volans L. Ravintobiologiasta (feeding biology of flying squirrel, in Finnish). Master's Thesis, University of Oulu, Finland. 1981.

20. Mäkelä A. Liito-oravan (Pteromys volans L.) ravintokohteet eri vuodenaikoina ulosteanalyysin perusteella (diet of flying squirrel, in Finnish). Helsinki: WWF Finland Reports 8; 1996. p. 54-8

21. Hanski IK, Mönkkönen M, Reunanen P, Stevens PC. Ecology of the Eurasian flying squirrel (Pteromys volans) in Finland. In: Goldingay R, Scheibe J, editors. Biology of gliding mammals. Furth (Germany): Filander; 2000. p. 67-86.

22. Sulkava P, Sulkava R. Liito-oravan ravinnosta ja ruokailutavoista KeskiSuomessa (feeding habits of flying squirrel; in Finnish). Luonnon tutkija. 1993;97:136-8

23. Selonen V, Wistbacka R, Korpimäki E. Food abundance and weather modify reproduction of two arboreal squirrel species. J Mammal. 2016;97:1376-84

24. Hanski IK, Selonen V. Female-biased natal dispersal in the Siberian flying squirrel. Behav Ecol. 2009;20:60-7

25. Selonen V, Painter JN, Rantala S, Hanski IK. Mating system and reproductive success in the Siberian flying squirrel. J Mammal. 2013;94:1266-73.

26. Selonen V, Hanski IK, Wistbacka R. Communal nesting is explained by subsequent mating rather than kinship or thermoregulation in the Siberian flying squirrel. Behav Ecol Socio. 2014;68:971-80.

27. Lampila S, Wistbacka A, Mäkelä A, Orell M. Survival and population growth rate of the threatened Siberian flying squirrel (Pteromys volans) in a fragmented forest landscape. Ecoscience. 2009;16:66-74.

28. Hokkanen T. Seed crops and seed crop forecasts for a number of tree species. In: Mälkönen E, Babich NA, Krutov VI, Markova IA, editors. Forest regeneration in the northern parts of Europe. Proceedings of the FinnishRussian forest regeneration seminar in Vuokatti, Finland, Sept 28th-Oct 2nd, 1998. Metsäntutkimuslaitoksen tiedonantoja-The Finnish Forest Research Institute, Research Papers. 2000:790: 87-97.

29. Rousi M, Heinonen J. Temperature sum accumulation effects on withinpopulation variation and long-term trends in date of bud burst of European white birch (Betula pendula). Tree Physiol. 2007;27:1019-25.

30. Burnham KP, Anderson DR. Model selection and multimodel inference: a practical information-theoretic approach. 2nd ed. New York: Springer; 2002

31. Post E, Forchhammer MC. Climate change reduces reproductive success of an arctic herbivore through trophic mismatch. Phil Trans Roy Soc Lond B. 2008:363:2369-75.

32. Eeva T, Veistola S, Lehikoinen E. Timing of breeding in subarctic passerines in relation to food availability. Can J Zool. 2000;78:67-78.

33. Possen BJHM, Oksanen E, Rousi M, Ruhanen H, Ahonen V, Tervahauta A, Heinonen J, Heiskanen J, Kärenlampi S, Vapaavuori EM. Adaptability of birch (Betula pendula Roth) and aspen (Populus tremula L.) genotypes to different soil moisture conditions. Forest Ecol Manage. 2011;262:1387-99.

34. Marcello GJ, Wilder SM, Meikle DB. Population dynamics of a generalist rodent in relation to variability in pulsed food resources in a fragmented landscape. J Anim Ecol. 2008:77:41-6.

35. Kager T, Fietz J. Food availability in spring influences reproductive output in the seed-preying edible dormouse (Glis glis). Can J Zool. 2009;87:555-65.

36. Smith CC. The coevolution of pine squirrels (Tamiasciurus) and conifers. Ecol Monogr. 1970;40:349-71.

37. Fletcher $\mathrm{QE}$ ، Boutin S, Lane JE, LaMontagne JM, McAdam AG, Krebs CJ, Humphries MM. The functional response of a hoarding seed predator to mast seeding. Ecology. 2010;91:2673-83. 
38. LaMontagne JM, Williams CT, Donald JL, Humphries MM, McAdam AG, Boutin S. Linking intraspecific variation in territory size, cone supply, and survival of North American red squirrels. J Mammal. 2013;94:1048-58.

39. Larsen KW, Becker CD, Boutin S, Blower M. Effects of hoard manipulations on life history and reproductive success of female red squirrels (Tamiasciurus hudsonicus). J Mammal. 1997;78:192-203.

40. Bieber C. Population dynamics, sexual activity, and reproduction failure in the fat dormouse (Myoxus glis). J Zool. 1998;244:223-9.
41. Pilastro A, Tavecchia G, Marin G. Long living and reproduction skipping in the fat dormouse. Ecology. 2003;84:1784-92.

42. Kelly D, Sork VL. Mast seeding in perennial plants: why, how, where? Annu Rev Ecol Syst. 2002;33:427-47.

43. Yang LH, Edwards KF, Byrnes JE, Bastow JL, Wright AN, Spence KO. A meta-analysis of resource pulse-consumer interactions. Ecol Monogr. 2010;80:125-51.

\section{Submit your next manuscript to BioMed Central and we will help you at every step:}

- We accept pre-submission inquiries

- Our selector tool helps you to find the most relevant journal

- We provide round the clock customer support

- Convenient online submission

- Thorough peer review

- Inclusion in PubMed and all major indexing services

- Maximum visibility for your research

Submit your manuscript at

www.biomedcentral.com/submit 